\title{
Water security and detection of Cryptosporidium spp. in samples trom the Guarapiranga Reservoir, São Paulo
}

\section{Segurança hídrica e detecção de Cryptosporidium spp. em amostras de água da Represa de Guarapiranga, São Paulo}

Alessandra Barone Briani Fernandes ${ }^{1}$, Vanessa Aparecida Feijó de Souza² Flavio Aparecido Baldisseri Junior², Renata Ferraz de Toledo², Carla Alice Guelli3 ${ }^{3}$ Marcia Cristina Menão ${ }^{2}$, Alessandra Marnie Martins Gomes de Castro²

\section{RESUMO}

A segurança hídrica depende, dentre outros fatores, do ciclo hidrológico, quantidade e qualidade da água. Diversos microrganismos que oferecem riscos à saúde humana e animal são de veiculação hídrica, como o protozoário Cryptosporidium spp. Seu diagnóstico parasitológico, em material biológico e amostras ambientais, pode ser realizado por meio de diversas técnicas que incluem a microscopia óptica com análise de material a fresco ou pela da utilização de técnicas de concentração, imunofluorescência indireta e biologia molecular que permite a diferenciação entre as espécies. Pelo fato de oocistos de Cryptosporidium spp. serem eliminados pelas fezes de hospedeiros parasitados e lançados em reservas de água que podem ser utilizadas para consumo, faz-se necessária a identificação parasitária causadora de alterações gastrointestinais humanas. O objetivo deste trabalho foi verificar a presença de oocistos de Cryptosporidium spp. em áreas recreativas da Represa Guarapiranga localizada no Estado de São Paulo, Brasil, por meio da Técnica de Ziehl Neelsen. As amostras foram coletadas e processadas entre os meses de julho a novembro e mostraram resultados positivos para presença de oocistos de Cryptosporidium spp., bem como presença de cianobactérias, naturais na biota aquática, mas que podem ser encontradas em grande quantidade em ambientes eutrofizados pelo excesso de matéria orgânica lançada em reservas de água. Os oocistos foram observados em $60 \%$ das amostras analisadas e a distribuição entre positivos e negativos não foi dependente do mês de amostragem. Por outro lado, foi estatisticamente significativa a distribuição de amostras positivas e negativas dependentes do local de amostragem.

Palavras-chave: Cryptosporidium spp. Diagnóstico parasitológico. Represa de Guarapiranga.

\section{ABSTRAC}

Water security depends, among other factors, on the hydrological cycle, quantity and quality of water. Several microorganisms that pose risks to human and animal health are waterborne, such as the protozoan Cryptosporidium spp. The parasitological diagnosis of Cryptosporidium spp. in biological material and environmental samples can be accomplished through several techniques that include optical microscopy with analysis of fresh material or through the use of concentration techniques, indirect immunofluorescence and molecular biology that allows differentiation between species. Oocysts of Cryptosporidium spp. are eliminated through feces from parasitized hosts and released into drinking water reservoirs through untreated sewage. Therefore, its proper identification is necessary when causing human gastrointestinal changes. The objective of this work is to analyze the presence of oocysts of Cryptosporidium spp. in recreational areas of the Guarapiranga Resevoir located in the state of São Paulo, Brazil. Water samples were collected and concentrated between July and November and analyzed through the technique of Ziehl Neelsen. Samples showed positive results for Cryptosporidium spp. and cyanobacteria, which are commonly found in the aquatic biota. The latter can be found in large quantities in eutrophic environments due to high amount of organic matter released in water bodies. Oocysts were observed in $60 \%$ of the analyzed samples and the distribution between positive and negative samples was not dependent on the month of sampling, but showed statistically significant differences according to the sampling site.

Keywords: Cryptosporidium spp. Parasitological diagnosis Guarapiranga Reservoir
${ }^{1}$ Mestre. Centro Universitário das Faculdades Metropolitanas Unidas, Faculdade de Biomedicina, Campus Liberdade. Avenida da Liberdade, 899. Liberdade. CEP 01503-001. São Paulo, SP. Brasil.

E-mail:

alessandra.fmu@gmail.com

${ }^{2}$ Doutor. Centro Universitário das Faculdades Metropolitanas Unidas, Programa de PósGraduação em Saúde Ambiental, Faculdade de Medicina Veterinária, Campus Ponte Estaiada. Rua Ministro Nelson Hungria, 541. Real Parque. Morumbi. CEP 05690-050. São Paulo, SP. Brasil.

${ }^{3}$ Mestre. Centro Universitário das Faculdades Metropolitanas Unidas, Faculdade de Fisioterapia, Campus Liberdade. Avenida da Liberdade, 899. Liberdade. CEP 01503-001. São Paulo, SP. Brasil. 


\section{INTRODUCĀO}

Water is a natural renewable resource dependent on factors associated with the hydrological cycle, quantity, quality and, especially, water security. Indicators from the Intergovernmental Panel on Climate Change (IPCC) show that approximately $80 \%$ of the world's population is threatened by water unavailability, demand or contamination (SORIANO et al., 2016; JACOBI et al., 2016).

In Brazil, these threats are strongly present, especially in the state of São Paulo, due to its high demographic density and an increasing demand for water by industrial, agricultural and human consumption. However, only $6 \%$ of Brazilian water resources are available for these purposes (ISA, 2014). Specifically in the metropolitan region of São Paulo, with its more than 20 million inhabitants and 39 municipalities, the strong demand for water is exacerbated by the disorderly use and occupation of the soil, in valleys, river floodplains and water source areas, the high load of domestic and industrial untreated effluents shed on water bodies and, the lack of planning in the management of the reservoirs that supply this region (JACOBI et al., 2015, OLIVER e RIBEIRO, 2014).

The Guarapiranga Reservoir, the focus of this research, together with the Billings Reservoir, supply 14 thousand liters of water per second to more than 3.5 million inhabitants in the south and southwest of São Paulo metropolitan area. The former is strongly threatened because, although located in a Water Supply Protection Area since 1975, rather restrictive state laws have not been able to prevent the occupation of its banks by poor basic sanitation settlements that aggravated its degradation. In addition, the Guarapiranga Reservoir is considered shallow, only 6 to 8 meters deep on average, which favors the accumulation of pollutants, as well as the seasonal proliferation of cyanobacteria, which can be harmful to human and animal health (OLIVER e RIBEIRO, 2014; BALTRUSIS e ANCONA, 2006).

Cryptosporidium spp. is the central concern of this research, especially because its oocysts are resistant to diverse environmental harsh conditions, even to the process of chlorination commonly used in water treatment plants (LIMA e STAMFORD, 2003).

Cryptosporidium spp. are protozoa that infect the microvilli cells of the gastrointestinal epithelium and the respiratory tract mucosa of a wide range of vertebrates, including humans, causing inflammation and atrophy of the intestinal villi and lung diseases (MEIRELES, 2010, SKOTARCZAK, 2010). 
Cryptosporidiosis is prevalent in practically all Brazilian geographic regions, showing high variation on registered case indexes. The present study data reinforce the endemic character of this parasitosis in several Brazilian specific locations.

The main form of transmission of Cryptosporidium spp. occurs by ingestion of contaminated food and water. The person-person and person-animal transmission is a consequence of the anthropozoonotic activity of some species of Cryptosporidium. Immunodeficient individuals have a higher positivity rate in the countries where the agent was detected (PUTIGNANI e MENICHELLA, 2010).

Despite being a waterborne agent, its dissemination is greatly facilitated and increased by the large amount of oocysts eliminated in the feces of infected hosts (MARTINS-VIEIRA et al., 2009).

The methods of detection of oocysts in water samples are based on three stages: collection and concentration of water samples, purification and identification of the protozoa (FRANCO et al., 2012a).

The main techniques for the visualization of the agent are stained permanent glass slide preparations such as the technique of safranin-methylene blue and its variations, Ziehl Neelsen original technique and its 1981 modified version by Henriksen e Pohlenz (De CARLI, 2007; FRANCO et al., 2012b). The limitation of these techniques is the coloration of some unspecific organic materials which can impair proper visualization of the agent. However, a well-trained professional can easily overcome this issue (OZAKI, 2009).

Several waterborne diseases are influenced by changes in the hydrological cycles (PATZ e CHRISTENSON, 2010). The city of São Paulo faced a major water crisis in 2014, after the hottest and driest summer in 70 years (BBC Brazil, 2014). Several measures were taken by SABESP, the local water management state company, to minimize water consumption. The lack of rainfall was only one of the factors that contributed to the worsening of water quality in the reservoirs that supply the city of São Paulo (Table 1) that year. The lessening of the evolution of the domestic sewage treatment index directly interfered with the water quality of rivers and reservoirs (MAYARA, 2015).

Guarapiranga and Billings Reservoirs are the most important for the rainwater drainage of the metropolitan region of the city of São Paulo (OLIVER e RIBEIRO, 2014). Thus, the drought period rapidly resulted in a decrease of water availability, which is one of the factors that influenced the water quality of these reservoirs due to the lower dilution of 
pollution and all other components of water, including microorganisms (OTOMO et al., 2015).

The main objective of this study was the detection of the waterborne Cryptosporidium spp. by means of the 1981 Henriksen \& Pohlenz modified Ziehl Neelsen technique in water samples from the Guarapiranga Reservoir, São Paulo, Brazil.

Table 1. Minimum and maximum mean temperature and average rainfall recorded in the city of São Paulo in 2016.

\begin{tabular}{lccc}
\hline \multicolumn{1}{c}{ Months } & \multicolumn{2}{c}{ Air Temperature $\left({ }^{\circ} \mathbf{C}\right)$} & Average Rainfall (mm) \\
\hline Minimum & Maximum & \\
\hline January & 18.5 & 28.1 & 168.5 \\
February & 19.6 & 30.3 & 338.4 \\
March & 18.5 & 28.9 & 193.8 \\
April & 17.5 & 30.0 & 2.8 \\
May & 13.8 & 23.3 & 151.57 \\
June & 10.2 & 21.3 & 179.6 \\
July & 11.1 & 24.0 & 7.4 \\
August & 11.8 & 23.8 & 73.3 \\
September & 13.3 & 23.8 & 24.6 \\
October & 15.8 & 26.2 & 82.2 \\
November & 16.2 & 26.0 & 187.7 \\
December & 17.5 & 29.4 & 137.7 \\
\hline
\end{tabular}

Source: Annual Weather Report of the IAG-USP Weather Station, 2016

\section{MATERIAIS E METODOS}

Surface water samples were collected from July to November 2016 in three distinct sites of the Guarapiranga Reservoir, two of which are recreational areas, close to dense populated centers and one site located further away from these areas. The three sites are identified in Figure 1.

The ten liter water samples were concentrated by spontaneous sedimentation for a period of 24 hours. Nine liters of the supernatant were syphoned and discarded without disturbing the sediment. The remaining liter was re-suspended and subjected to filtration using a $3 \mu \mathrm{m}$ nominal porosity membrane and a vacuum pump for the retention of the oocysts according to the protocol used by FRANCO et al. (2012b), shown in figure 2. 
The saturated membranes were transferred to sterile Petri dishes and washed with a $0.01 \%$ Tween 80 solution for pelleting and disaggregation of the oocysts. This suspension was washed with $0.9 \%$ saline solution and centrifuged at $1050 \mathrm{~g}$ per $10 \mathrm{~min}$ for pellet production. This procedure was repeated twice. The pellet samples were used in the glass slide preparations and further microscopy analysis (FRANCO et al., 2012a; BOSA, 2014).

The material obtained by membrane filtration was used to prepare thin smear stained glass slides according the Ziehl Neelsen technique (De CARLI, 2007). A total of 75 glass slides were prepared, five per collection site per month.

The glass slide smears were stained with phenolic fuchsine until the emission of vapors, distained with $2 \%$ aqueous sulfuric acid solution for 30-60 seconds and stained with methylene blue for three minutes for background differentiation. The glass slides were analyzed under optical microscopy with 40x and 100x objective lenses.

Pearson's $X^{2}$ test was used to compare the positive and negative samples of Cryptosporidium spp., grouped by the months of collection and collection sites, at a significance level of $5 \%$ (VIEIRA, 2003).

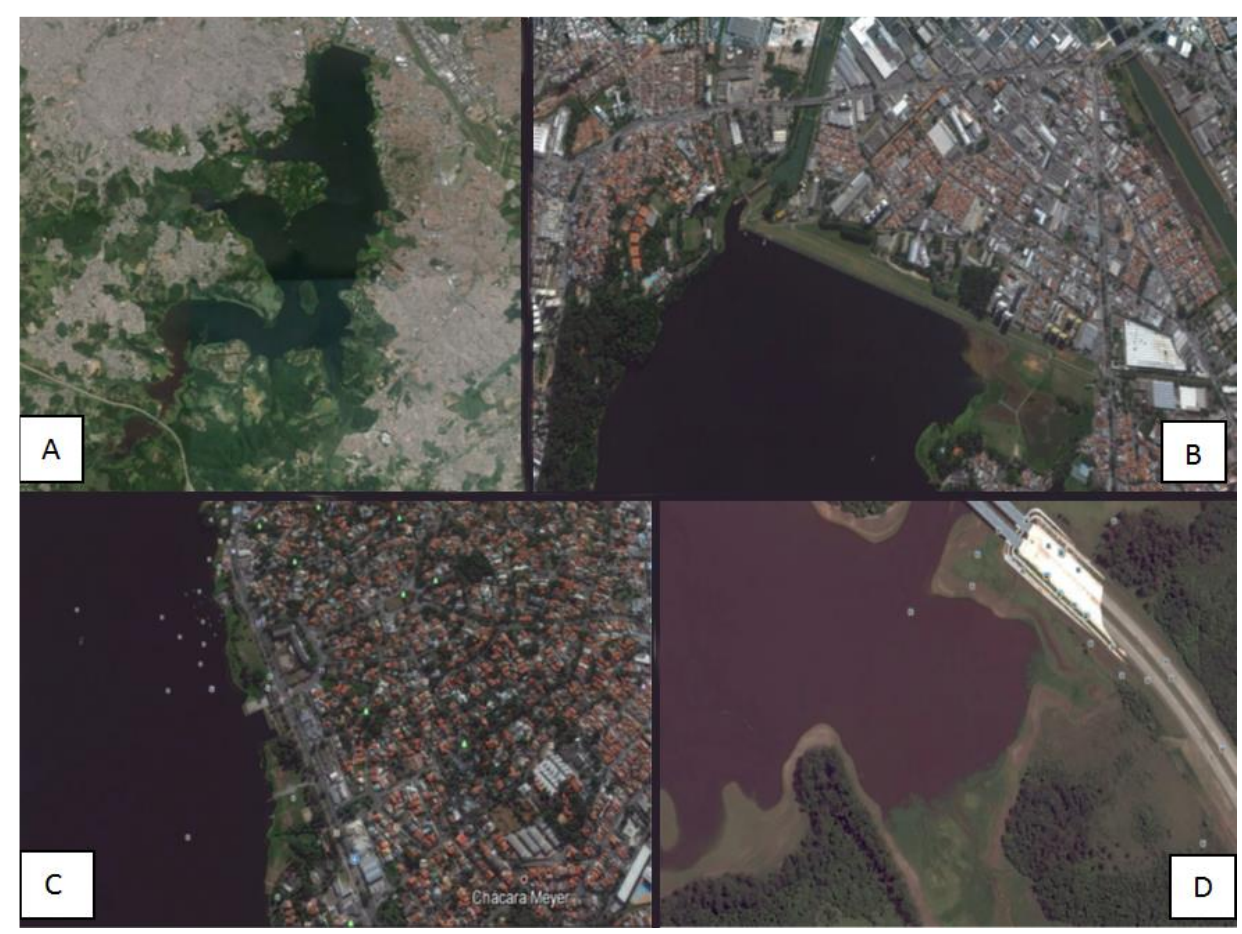

Figure 1. Google Earth Satellite image of the Guarapiranga Reservoir. A. Panoramic view of the Reservoir at $31 \mathrm{~km}$ altitude. B. Collection site B, Guarapiranga River mouth in the Socorro neighborhood (234' $12^{\prime \prime S}$ and $\left.46^{\circ} 42^{\prime} 56^{\prime \prime W}\right)$ at $8.7 \mathrm{~km}$ of altitude. C. Collection 
site C, Meyer Farm (2340'26"S and 464' $\left.{ }^{\prime} 7^{\prime \prime W}\right)$ at $8.7 \mathrm{~km}$ of altitude. D. Collection site D, inhabited area by in the Mario Covas Rodoanel Highway (2345'85"S and 4646'03"W) at $2.76 \mathrm{~km}$ of altitude.

\section{RESULTADOS}

The oocysts of Cryptosporidium spp. were identified in 60\% (45/75) of the analyzed glass slides. All other positive slides showed the presence of low parasitic load, that is, one to two oocysts per 50 analyzed microscope fields. The only glass slide smears negative for Crypstoporidium spp. oocytes were the ones from collection site $D$ in the month of August. Results are briefly presented in table 2.

Considering the months in which the samples were collected, a higher positivity was observed in the month of October [73.3\% (11/15)], followed by the months of November and September. The lowest number of positive results were obtained in August [46.7\% $(7 / 15)]$.

Table 2. Distribution of positive and negative samples for Crypstoporidium spp. by months and collection sites.

\begin{tabular}{cccc}
\hline Months & Collection site & Positives & Negatives \\
\hline \multirow{3}{*}{ July } & B & 4 & 1 \\
& C & 3 & 2 \\
& D & 1 & 4 \\
\hline \multirow{2}{*}{ August } & B & 5 & 0 \\
& C & 2 & 3 \\
September & D & 0 & 5 \\
& B & 4 & 1 \\
& C & 3 & 2 \\
October & D & 2 & 3 \\
& B & 5 & 0 \\
& C & 4 & 1 \\
\hline \multirow{3}{*}{ November } & D & 2 & 3 \\
& B & 4 & 1 \\
& C & 4 & 3 \\
\hline
\end{tabular}


Pearson's $x^{2}$ test was applied primarily for the data grouped by the collection months (Table 3) and later for the collection sites (Table 4).

The calculated value of $X^{2}(1.1)$ was not statistically significant at 5 degrees of freedom and $p=0.05$. Thus, the distribution between positive and negative samples was not dependent on the month of sampling. On the other hand, the value of $X^{2}(7.61)$ was statistically significant at 3 degrees of freedom and $p=0.05$, showing that the distribution of positive and negative samples depended on the sampling site.

Cyanobacteria of the genera Chroococcus, Synechocystis and Geitlerinema and Chlorophyceae of the genera Monactinus, Parapediastrum, Pediastrum and Desmodesmus were present in all samples.

No other parasitic forms, such as enteroparasite cysts or helminth eggs, were found in any of the glass slides.

Table 3. Observed and expected frequencies for positive and negative samples of Cryptosporidium spp., grouped by months of collection.

\begin{tabular}{lcccccc}
\hline \multirow{2}{*}{ Months } & \multicolumn{3}{c}{ Observed Frequency } & \multicolumn{3}{c}{ Expected Frequency } \\
\cline { 2 - 7 } & $\begin{array}{l}\text { Positive } \\
\text { Samples }\end{array}$ & $\begin{array}{l}\text { Negative } \\
\text { Samples }\end{array}$ & Total & $\begin{array}{l}\text { Positive } \\
\text { Samples }\end{array}$ & $\begin{array}{c}\text { Negative } \\
\text { Samples }\end{array}$ & \multirow{2}{*}{ Total } \\
\hline July & 8 & 7 & 15 & 9 & 6 & 15 \\
August & 7 & 8 & 15 & 9 & 6 & 15 \\
September & 9 & 6 & 15 & 9 & 6 & 15 \\
October & 11 & 4 & 15 & 9 & 6 & 15 \\
November & 10 & 5 & 15 & 9 & 6 & 15 \\
Total & 45 & 30 & 75 & 45 & 30 & 75 \\
\hline
\end{tabular}

Table 4. Observed and expected frequencies for positive and negative samples of Cryptosporidium spp., grouped by collection sites.

\begin{tabular}{ccccccc}
\hline \multirow{2}{*}{$\begin{array}{c}\text { Collection } \\
\text { Site }\end{array}$} & \multicolumn{2}{c}{ Observed Frequency } & \multicolumn{3}{c}{ Expected Frequency } \\
& Positive & Negative & Total & Positive & Negative & Total \\
& Samples & Samples & Samples & Samples & \\
\hline B & 22 & 3 & 25 & 15 & 10 & 25 \\
C & 16 & 9 & 25 & 15 & 10 & 25 \\
D & 7 & 18 & 25 & 15 & 10 & 25 \\
\hline Total & 45 & 30 & 75 & 45 & 30 & 75 \\
\hline
\end{tabular}




\section{DISCUSSÃO}

The presence of oocysts of Cryptosporidium spp. in all collection sites of the Guarapiranga Reservoir confirmed contamination by organic matter. However, the absence of parasitic forms of Cryptosporidium spp does not indicate water of drinking quality, especially because all the glass slides tested positive for cyanobacteria. The latter was present in large quantities, indicating a possible process of eutrophication due to excess of organic matter shed in the Guarapiranga Reservoir water. It would be necessary to use other environmental biomarkers along with Cryptosporidium spp., such as the quantification of fecal coliform bacteria, in order to confirm the contamination of the Guarapiranga Reservoir by untreated sewage (LIMA e STAMFORD, 2003).

The positive glass slide preparations for Cryptosporidium spp. showed low parasite load in the sediment pellets obtained from ten liter water samples. This level of contamination can be considered non infective for immunocompetent individuals who use the Guarapiranga Reservoir for leisure. On the other hand, as there is evidence of the presence of excess organic matter in all collection sites, attested by the large quantities of cyanobacteria found, this indicates the possibility of the presence of species of enterobacteria, also at infective levels.

The variations found over the collection months may be related to variation in rainfall in the metropolitan region of the city of São Paulo (IAG-USP, 2016). According to the data presented in Table 1, it can be observed that the rainfall index in the July, August and September quarter remained at low levels compared to the rest of the year. It is known that the least amount of rainfall negatively influences the presence of parasitic forms in the sediment at the bottom of the reservoir. This could help to explain the least amount of positive results found in those months (MAYARA, 2015).

In the months of October and November, an increment in rainfall was observed, allowing the precipitation of oocysts by water movement, increasing the index of positive results (IAG-USP, 2016).

According to COBRAPE (Project and Development Brazilian Company) in the report "Updating of the Development Plan and Environmental Protection of the Guarapiranga Basin", the quality of the water in the reservoir is the result of the interaction of several 
factors, some of them exclusively of an environmental nature, related to the climatic cycles and the ecological dynamics of the lake, and others resulting from the human activities that generate permanent flows of pollutant loads. The concentration of pollutants available in the water are due to both external loads, released in a concentrated way by the effluents, as well as internal loads, from sediment layers by resurgence (SEMA, 2016).

Studies carried out by Stancarli and Correia (2010), which were based on the collection of 30 seasonal samples of water in the water treatment stations of five municipalities of the state of São Paulo during periods of drought (May, August and September 2006) in the rainy season (January and February 2007) and again in the dry season (August and September 2007), were negative for both untreated and treated water, regardless of the season analyzed.

Araújo et. al (2011) analyzed water samples from the Guarapiranga Reservoir from 2005 to 2006. The ten liter samples were concentrated by membrane filtration technique and the pellets analyzed by Nested-PCR. Only nine out of 30 samples were positive for Cryptosporidium hominis with no influence of seasonality.

Franco et al. (2001) investigated cysts of Giardia duodenalis and oocysts of Cryptosporidium spp. in water samples from the Atibaia River, concentrated by membrane filtration and analyzed by immunofluorescence. All samples were positive for Cryptosporidium spp. oocysts. According to the authors, although the filtration technique caused particle compaction around the oocysts, generating false negative results, the immunofluorescence technique was effective for the identification of the parasitic forms of Cryptosporidium spp.

Despite the 1975 environmental protection laws for the conservation of water resources and control of the illegal occupation of natural areas of permanent preservation, the human population around the Guarapiranga Reservoir increased by almost $40 \%$ between 1991 and 2000, contributing to environment degradation and the discharge of untreated sewage into its lake, which is used for recreation, fishing and as a water source for the population of the city of São Paulo (ISA, 2006).

The urbanization model in the Metropolitan Region of São Paulo city has altered the local climate and has resulted in both the increase in air temperature and changes in the daily distribution of rainfall. The expansion of the urban road network towards the water source areas add to the pollution problems resulting from the illegal occupation of these areas to the effects of climate variability (OLIVER e RIBEIRO, 2014). 
The recent water crisis experienced by the population of the city of São Paulo, which was mainly caused by lack of rainfall and due to an increase in water demand, lowering the water level of the reservoirs showed the necessity to create monitoring centers to control illegal occupation of the water source areas, to avoid degradation of the environment in areas of permanent protection and to implement the expansion of the sewage treatment network to improve water quality (BBC Brasil, 2014; XAVIER, 2014).

\section{CONSIDERACOES FINAIS}

The remaining challenge is to protect the water resources, improve urban living conditions and guarantee the right to housing, sanitation and health. The access to drinking water and sanitation, as well as the reduction of inequalities and the construction of sustainable communities and cities are among the 17 Global Objectives for Sustainable Development (MACHADO Fo, 2015), which are fundamental to guarantee water security to the population.

\section{REFERÉNCIAS}

ARAÚJO, R. S.; DROPA, M.; FERNANDES, L. M.; CARVALHO, T. T.; SATO, M. I. Z; SOARES, R. M.; MATTÉ, G. R.; MATTÉ, M. H.. Genotypic Characterization of Cryptosporidium hominis from Water Samples in São Paulo, Brazil. The American Journal of Tropical Medicine Hygiene, v.85, n.5, p.834-838, 2011.

BALTRUSIS, N.; ANCONA, A. L.. Recuperação ambiental e saúde pública. O Programa Guarapiranga. Saúde e Sociedade, v.15, n.1, p.9-21, 2006.

\section{BBC Brasil. Maior crise hídrica de SP expõe lentidão do governo e sistema frágil.} 2014. Disponível em <http://noticias.terra.com.br/brasil/maior-crise-hidrica-de-sp-expoelentidao-do-governo-e-sistemafragil,5350dd5ab0ae4410VgnVCM4000009bcceb0aRCRD.html>. Acesso em 12 de junho de 2016.

BOSA, C. R.. Detecção e Identificação de Cryptosporidium spp. Tyzzer, 1907 em fezes de animais e água do zoológico Municipal de Curitiba, Paraná, Brasil. 2014. 
109f. Tese de Doutorado em Microbiologia, Parasitologia e Patologia. Universidade Federal do Paraná, Paraná, 2014.

De CARLI, G. A.. Parasitologia Clínica: seleção de métodos e técnicas de laboratório para o diagnóstico das parasitoses humanas. 2ed. São Paulo: Editora Atheneu, 2007.

FRANCO, R. M. B.; EBERHARDT, R. R.; NETO, R. C.. Occurrence of Cryptosporidium oocysts and Giardia cysts in raw water from the Atibaia river, Campinas, Brazil. Revista Instituto de Medicina Tropical de São Paulo, v.43, n.2, p.109-111, 2001.

FRANCO, R. M. B; BRANCO, N; LEAL, D. A. G.. Parasitologia ambiental: Método de Concentração e Detecção de Cryptosporidium spp. e Giardia spp. em amostras de água. Revista de Patologia Tropical, v.41, n.2, p.119-135, 2012a.

FRANCO, R. M. B.; HACHICH, E. M.; SATO, M. I. V.; NAVEIRA, R. M. L.; SILVA, E. C.; CAMPOS, M. M. C.; NETO, R. C.; CERQUEIRA, D. A.; BRANCO, N.; LEAL, D. A. G.. Avaliação da performance de metodologias de detecção de Cryptosporidium spp. e Giardia spp. em água destinada ao consumo humano, para o atendimento às demandas da Vigilância em Saúde Ambiental no Brasil. Epidemiologia e Serviços de Saúde. Brasília, v.21, n.2, p.233-242, 2012b.

\section{IAG-USP. Boletim Climatológico Anual da Estação Meteorológica do IAG/USP/} Seção Técnica de Serviços Meteorológicos - Instituto de Astronomia, Geofísica e Ciências Atmosféricas da Universidade de São Paulo - v.19, 2016.

ISA - Instituto Sócio-Ambiental. Seminário Guarapiranga. Diagnóstico Socioambiental participativo da Guarapiranga. 2006. Disponível em:

<https://www.socioambiental.org/banco_imagens/pdfs/10288.pdf >. Acesso em 12 de abril de 2016.

ISA - Instituto Sócio-Ambiental. Água doce e limpa: de "dádiva" à raridade. Disponível em: <https://site-antigo.socioambiental.org/esp/agua/pgn/>. Acesso em 21 de abril de 2016. 
JACOBI, P. R.; CIBIM, J.; LEÃO, R. S.. Crise Hídrica na Macrometrópole Paulista e respostas da sociedade civil. Estudos Avançados, v.29, n.84, p.27-42, 2015.

JACOBI, P. R; EMPINOTTI, V. L.; SCHMIDT, L.. Water Scarcity and Human Rights. Ambient. Soc., v.19, n.1, 2016. Editorial.

LIMA, E. C.; STAMFORD, T. L. M.. Cryptosporidium spp. no ambiente aquático: aspectos relevantes da disseminação e diagnóstico. Ciência \& Saúde Coletiva, São Paulo, v.8, n.3, p.791-800, 2003.

MARTINS-VIEIRA, M. B. C.; BRITO, L. A. L.; HELLER, L.. Oocistos de Cryptosporidium parvum em fezes de bezerro infectado experimentalmente. Arquivo Brasileiro de Medicina veterinária e Zootecnia, v.61, n.6, p.1454-1458, 2009.

MAYARA, C.. Estudo da Cetesb mostra piora na qualidade da água na Billings. 19 de Maio de 2015. Rede Brasil Atual, seção ambiente. Disponível em <http://www.redebrasilatual.com.br/ambiente/2015/05/estudo-da-cetesb-mostra-piora-naqualidade-da-agua-na-billings-2712.html $\geq$. Acesso em 21 Nov. 2016.

MEIRELLES, M. V.. Cryptosporidium infection in Brazil: implications for veterinary medicine and public health. Rev. Bras. Parasitol. Vet., Jaboticabal, v.19, n.4, p.197-204, 2010.

OLIVER, S. L; RIBEIRO, H.. Variabilidade climática e qualidade da água do Reservatório Guarapiranga. Estudos Avançados, v.28, n.82, p.95-128, 2014.

MACHADO Fo, H.. Org. Documentos Temáticos - Objetivos de Desenvolvimento Sustentável, seções 1, 2, 3, 5, 9 e 14. ONUBR - Nações Unidas no Brasil, Junho de 2017, 103p..

OZAKI, S. C.. Cryptosporidium spp.: desenvolvimento de técnicas moleculares e imunoquímicas para a deteç̧ão de oocistos em água e avaliação da sua remoção 
pelos métodos convencionais de tratamento de água. 2009. 174fl. Tese apresentada ao Curso de Pós-Graduação em Processos Biotecnológicos- Universidade Federal do Paraná. Curitiba, 2009.

PATZ, J. A.; CHRISTENSON, M.. El cambio climático y la salud. In: determinantes ambientales y sociedades de la salud. México: Organización Panamericana de la Salud, p.215-232, 2010.

OTOMO, J. I. et al.. Avaliação de políticas para preservação e recuperação de mananciais de abastecimento público da região metropolitana de São Paulo. Cap.25, p.376-395. In: Pompeo, M; et.al. Orgs. Ecologia de reservatórios e interfaces. São Paulo: Instituto de Biociências da Universidade de São Paulo, 2015.

PUTGNANI, L.; MENICHELLA, D.. Global Distribution, Public Health and Clinical Impact of the Protozoan Pathogen Cryptosporidium. Interdisciplinary Perspectives on Infectious Diseases, v.2010, p.1-39.

SEMA (Secretaria do Meio Ambiente) - São Paulo. Atualização do Plano de Desenvolvimento e Proteção Ambiental da Bacia Hidrográfica do Guarapiranga. 2016. Disponível em <http://www.ambiente.sp.gov.br/cpla/2013/03/14/aprm-area-deprotecao-e-recuperacao-de-mananciais/>. Acesso em 04 Jan. 2017.

SKOTARCZAK, B.. Progress in the Molecular Methods for the detection and Genetic characterization of Cryptosporidium in water samples. Annals Agricultural Environmental Medicine, v.17, n.1, p.1-8, 2010.

SORIANO, E; LONDE, R. L.; Di GREGORIO, L. T.; COUTINHO, M. P.; SANTOS, L. B. L.. Crise Hídrica em São Paulo sob o ponto de vista dos desastres. Ambiente \& Sociedade. São Paulo, v.19, n.1, p.21-42, 2016.

STANCARLI, R. C. A.; CORREIA, M. Detecção de oocistos de Cryptosporidium spp e cistos de Giardia spp. em mananciais e águas de abastecimento público. Revista Instituto Adolfo Lutz, v.69, n.4, p.453-460, 2010. 
VIEIRA, S.. Bioestatística: Tópicos Avançados. Testes não-paramétricos, tabelas de contingência e análise de regressão. 2ed. Rio de Janeiro: Elsevier, 2003. 216p.

XAVIER, M.. O drama da crise hídrica em São Paulo. O resultado das medidas de emergência e as obras para enfrentar uma das maiores estiagens da história e evitar o racionamento na capital. Revista Veja São Paulo, 2014. Disponível em <http://vejasp.abril.com.br/materia/racionamento-drama-medidas-solucoes-falta-aguavolume-morto>. Acesso em: 12 Jun. 2016. 